\title{
Responses of desert grassland vegetation to mesquite removal and regrowth
}

\author{
ARTHUR R. TIEDEMANN AND JAMES O. KLEMMEDSON
}

Authors: Scientist Emeritus, Pacific Northwest Research Station, 1401 Gekeler Lane, LaGrande, Ore. 97850, and Professor Emeritus, School of Renewable Natural Resources, 325 Biological Sciences East Bldg., University of Arizona, Tucson, Ariz. 85721.

\author{
Abstract
}

The purpose of this study was to determine the long-term response of understory vegetation in the desert grassland of southeastern Arizona, USA, to removal and regrowth of mesquite Prosopis juliflora (Swartz) DC. var. velutina (Wooton) Sarg. trees. The study involved 3 treatments applied to mesquite in 1966; mesquite left intact (MI), mesquite removed (MR), and mesquite removed, sprouted, and regrown (MRS). Vegetation responses to 2 litter treatments, litter intact (LI) and litter removed (LR), also were examined. Cover of understory vegetation and juvenile mesquite $(<\mathbf{1 . 5} \mathrm{m}$ height $)$ were measured in canopy and open (intercanopy) locations. Major changes between 1967 and 1991 were increased cover of juvenile mesquite, shrubs, halfshrubs, bush muhly Muhlenbergia porteri Scribn., and Lehmann lovegrass Eragrostis lehmanniana Nees., and a decline in cover of Arizona cottontop Digitaria californica (Benth.) Chase, and plains bristlegrass Setaria macrostachya H.B.K. Arizona cottontop, plains bristlegrass, and bush muhly were more abundant in canopy locations; black grama Bouteloua eriopoda Torr. and Lehmann lovegrass were more abundant in open locations. Lehmann lovegrass cover was lowest in canopy locations of the mesquite intact treatment. Combination of the mesquite removed and sprouted and litter intact treatments favored increased cover development of native perennial grasses. Litter removal enhanced cover development of Lehmann lovegrass, most likely through increased amount of red light and increased soil temperature fluctuations. Low levels of understory cover ( $22 \%$ average) probably facilitated recruitment of mesquite and other woody plants. Our observation that the greatest cover of Arizona cottontop, plains bristlegrass, and bush muhly occurred in the canopy location of the mesquite intact treatment suggests a potential strategy for maintaining diversity of native perennial grasses. Mature mesquite should be examined as a refuge for native species.

Key Words: plant succession, plant litter, Lehmann lovegrass, non-native grass

\footnotetext{
The authors gratefully acknowledge the cooperation of the Rocky Mountain Research Station, Fort Collins, Colorado for providing the area to conduct the study at the Santa Rita Experimental Range. We appreciate the thorough, candid technical reviews of the manuscript by Dr. Mitchel McClaran, University of Arizona, Tucson, and Dr. Bruce Roundy, Brigham Young University, Provo, Utah. We thank Dr. David Marx, University of Nebraska, Lincoln for statistical design and analyses of the data and for his helpful consultations with management of the data.

Manuscript accepted 3 Feb. 2004.
}

El objetivo de este estudio fue determinar la respuesta a largo plazo del estrato inferior de vegetación a la remoción y rebrote de árboles de "Mesquite" Prosopis juliflora (Swartz) DC. var. velutina (Wooton) Sarg. en los pastizales desérticos del sudeste de Arizona E.U.A. El estudio involucro tres tratamientos aplicados al "Mesquite" en 1966: "Mesquite" dejado intacto (MI), "Mezquite" Removido (MR) y "Mezquite" removido y con crecimiento de los rebrotes (MRS). También se examinó la respuesta de la vegetación a dos tratamientos de mantillo, mantillo intacto (LI) y mantillo removido ( $L R)$. La cobertura del estrato inferior de la vegetación y la de "Mezquites" Juveniles $(<1.5 \mathrm{~m}$ de altura) se midió en sitios abiertos (entre las copas de los arboles) y bajo la copa. Los cambios principales entre 1967 y 1991 fueron un aumento de la cobertura de "Mezquites" juveniles, arbustos, semiarbustos, "Bush muhly" Muhlenbergia porteri Scribn. y "Lehmann lovegrass" Eragrostis lehmanniana Nees. y la disminución de la cobertura de "Arizona cottontop" Digitaria californica (Benth.) Chase y "Plains bristlegrass" Setaria macrostachya H.B.K. El "Arizona cottontop", "Plains bristlegrass"y "Bush muhly"fueron más abundantes en los sitios bajo la copa; el "Black grama" Bouteloua eriopoda Torr. y Lehmann lovegrass" fueron más abundantes en los sitios abiertos. La cobertura más baja de "Lehmann lovegrass" se presentó en los sitios bajo la copa del tratamiento de "Mezquite" intacto. Los tratamientos de la combinación de "Mezquite" removido y rebrotado y mantillo intacto favorecieron el incremento de la cobertura de los zacates nativos perennes. La remoción de mantillo mejoro el desarrollo de la cobertura aérea del "Lehmann lovegrass", muy probablemente a través de un aumento en la cantidad de la luz roja y en las fluctuaciones de la temperatura del suelo. Los bajos niveles de cobertura del estrato inferior (22\% en promedio) probablemente facilitaron el establecimiento del "Mezquite" y otras plantas leñosas. Nuestras observaciones de que la mayor cobertura de "Arizona cottontop", "Plains bristlegrass" y "Bush muhly"ocurrió en los sitios de la copa del "Mezquite" intacto sugieren que una estrategia potencial para mantener la diversidad de los zacates nativos perennes. Los "Mezquite" maduros deben ser examinados como un refugio de especies nativas perennes.

The worldwide invasion of native woody plants in grasslands has been a pursuit of ecological research during the last 50 to 100 years (Archer et al. 1988, Turner et al. 1998). Invasion of mesquite (Prosopis spp.) into southwestern grasslands of the USA has been a focus of research and management since the 1950's (Parker and Martin 1952, Martin 1975, Martin and Morton 1993) because of associated reduction in forage production and 
increased soil exposure. Between the turn of the century and the early 1960's, mesquite expanded into 8 million ha of desert grassland in the southwestern U.S. and Mexico (Martin 1966).

Competition from invading mesquite has influenced density and production of herbaceous species, especially native grasses which are the principle ground cover and forage for livestock. The dynamics of this semidesert community are complex because of its vulnerability to plant invasion, disturbance from livestock grazing, and frequent drought (Cable 1969, 1976, Martin and Morton 1993, Angell and McClaran 2001). Seeding introduced species into southwestern grasslands has increased the complexity of plant community dynamics and has been a cause for interest and concern (Anable et al. 1992, McClaran and Anable 1992). Aggressive species, such as Lehmann lovegrass Eragrostis lehmanniana Nees. that have the potential to reduce cover and productivity of native species and reduce understory plant species diversity (Kincaid et al. 1959) are of particular concern. First seeded on the Santa Rita Experimental Range (SRER) in the 1930s for its potential to control erosion and provide forage, Lehmann lovegrass, an introduced $\mathrm{C} 4$ caespitose perennial grass native to South Africa (Cox et al. 1988), is now a common perennial at SRER (Angell and McClaran 2001). Research by McClaran and Anable (1992) supports the prediction of Cable (1971) that Lehmann lovegrass would spread far beyond the area of original seedings regardless of condition and management of adjacent land. Spread of Lehmann lovegrass has been estimated at 6 to 175 m.year ${ }^{-1}$ (Kincaid et al. 1959, McClaran and Anable 1992). Seedings of Lehmann lovegrass on 69,000 ha in Arizona between 1950 and 1980 had expanded to 145,000 ha by 1985 (Cox and Ruyle 1986). The success of Lehmann lovegrass can be attributed to its many traits common to aggressive, invasive species (Angell and McClaran 2001). Seeded Lehmann lovegrass could become the dominant herbaceous plant within 15 years of establishment, it's density has increased in both grazed and ungrazed plant communities, and it's spread to new locations is not related to grazing intensity (Anable et al. 1992, McClaran and Anable 1992).

In 1968, we completed studies of mesquite-desert grassland in Arizona designed to assess effects of shade, roots, and litter of mesquite trees Prosopis juliflora (Swartz) DC. var. velutina
(Wooton) Sarg. on soil physical and chemical properties and understory vegetation (Tiedemann and Klemmedson 1973a, 1973b, 1977). These and other studies showed that areas beneath mesquite canopies are associated with: improved soil physical conditions and enriched nutrient status (Tiedemann and Klemmedson 1973a, Barth and Klemmedson 1978, 1982); improved availability of soil nitrogen $(\mathrm{N})$ and sulfur $(\mathrm{S})$ (Tiedemann and Klemmedson 1973b); and reduced soil temperatures, increased soil moisture, and reduced net radiation (Tiedemann and Klemmedson 1977, Belsky et al. 1989). These influences of mesquite and many other shrubs (especially legumes) contribute to favorable understory environment for development of native, shade-tolerant perennial grasses (Tiedemann et al. 1971, Belsky et al. 1989, Belsky 1994).

Our original study involved 3 treatments applied to 24 mesquite trees of uniform stature approximately 4 to $5 \mathrm{~m}$ tall with canopies measuring 6 to $7 \mathrm{~m}$ diameter. Mesquite treatments were: 1) leaving mesquite intact, 2) removing mesquite, and 3 ) removing mesquite and replacing their canopies with artificial shade structures. There were 8 mesquite trees in each treatment category. We examined the effect of litter removal by removing litter from the entire canopy area and from the area encompassed by the vegetation transects in the open (intercanopy) area for half of the trees. We used a spring-tooth leaf rake to minimize soil disturbance. Measurements were made in canopy and open locations. Upon completion of the study, shade structures were removed and all plots were permanently marked. By 1980 , some of the trees cut in 1966 (and supposedly killed with oil application to stumps) had sprouted and regrown. Timing of sprouting was not determined. Sprouting was not yet evident in 1968 or 1969 , but by 1980 regrown trees were half to two-thirds the size of the 8 intact trees used in the study. This presented the opportunity to assess long-term responses of soil and vegetation to 2 of our original mesquite treatments plus a new treatment-sprouted and regrown mesquite.

Objectives of the new study, begun in 1981, were twofold: to determine the longterm influence of mesquite removal and regrowth and litter removal on 1) soil physical and chemical characteristics, findings since published (Klemmedson and Tiedemann 1986, Tiedemann and Klemmedson 1986) and 2) composition and cover of understory vegetation (including juvenile mesquite trees $<1.5 \mathrm{~m}$ height) in canopy and open locations of the treated plots. The latter objective is the focus of this paper.

In 1967, Lehmann lovegrass was a minor component on the study area and juvenile mesquite trees comprised only 0.1 percent cover. Because of current interest in the expansion of these species in the desert grassland, we designed the followup study to measure the effect of the 3 mesquite treatments and the litter treatment on Lehmann lovegrass and juvenile mesquite tree cover in canopy and open locations. We also wanted to assess changes in abundance of native perennial grasses in relation to any expansion of Lehmann lovegrass. Previous studies noted above suggest further encroachment of both mesquite and Lehmann lovegrass, especially the latter, on the study area. Open areas and plots with mesquite removed can be expected to enhance native perennial grasses, but Lehmann lovegrass, if present, would probably compete more aggressively for these sites (Cable 1976, Martin and Morton 1993). Earlier studies provide few clues on the effect of litter treatments on success of native vegetation and Lehmann lovegrass, or whether the latter might prefer canopy or open locations. Improved soil fertility and soil physical properties beneath mesquite canopies are 2 of the factors responsible for the abundance of native perennial grasses in that location. Removal of mesquite results in a shift in soil physical and chemical characteristics to those approximating open areas (Klemmedson and Tiedemann 1986 , Tiedemann and Klemmedson 1986). We anticipate these changes may adversely affect the native grass species-especially if Lehmann lovegrass also occupies these sites. Regrowth of mesquite trees reverses the trend toward open conditions for soil physical and chemical characteristics. Our expectation is that this reversal may favor native perennial grasses.

\section{The Study Area}

The study area was a 20 -ha desert grassland site (Study Area 45) at about $1100 \mathrm{~m}$ elevation on the SRER south of Tucson, Arizona, USA. Coordinates according to McClaran et al. (2002) for UTM are: X = 513118; Y = 3520276 (Projection: UTM, Zone 12. Datum: NAD 83. Spheroid: GRS80. Units: meters).

Domestic livestock had been excluded since 1937. Areas under mesquite canopies supported dense stands of herba- 
ceous vegetation, mainly native perennial grasses. By comparison, open areas were sparsely vegetated.

Soils are of Combate and Diaspar series (Breckenfeld and Robinett 1997). They are derived from alluvium of acid and basic igneous rocks, are coarse, deep, and well-drained. Combate series is a member of the coarse-loamy, mixed, superactive nonacid, thermic Ustic Torrifluvents. Diaspar series is a member of the coarseloamy, mixed, superactive, thermic Ustic Haplargids.

Mesquite dominates the overstory vegetation. Catclaw acacia Acacia greggii Gray, pricklypear and cholla Opuntia spp., and barrel cactus Ferocactus wislizeni (Engelm.) Britt. and Rose (Rosa spp.) are major shrubs and larger succulent plants. Burroweed Haplopappus tenuisectus (Greene) Blake and zinnia Zinnia pumila Gray are common halfshrubs. Major perennial grasses are Arizona cottontop Digitaria californica (Benth.) Chase, bush muhly Muhlenbergia porteri Scribn., plains bristlegrass Setaria macrostachya H.B.K., black grama Bouteloua eriopoda Torr., and Lehmann lovegrass. Needle grama Bouteloua aristidoides H.B.K. (Griseb) and sixweeks threeawn Aristida adscensionis $\mathrm{L}$. are the predominant annual grasses. A variety of forbs are present, but morning glory Evolvulus alsinoides L. is the most abundant.

Mean annual precipitation at the study site, 1936 to 2001 , is $37.7 \mathrm{~cm}$; mean July through September precipitation is 20.4 $\mathrm{cm}$ and comprises slightly more than half $(54 \%)$ of the total annual precipitation (Table 1). Summer temperatures are moderate; they exceed $38^{\circ} \mathrm{C}$ on only a few days each summer. Maxima of $21^{\circ} \mathrm{C}$ occur in all winter months; frost occurs an average of 25 days per year (Sellers 1960).

\section{Methods}

Sampling was carried out in each of 3 years $(1967,1981$, and 1991) to measure the response of vegetation (grasses, forbs, halfshrubs, shrubs, and juvenile mesquite) to 3 mesquite treatments [mesquite intact (MI), mesquite trees removed (MR), and mesquite trees removed, sprouted, and regrown (MRS)], 2 litter treatments [litter intact (LI) and litter removed (LR)], and 2 locations [canopy $(\mathrm{C})$ and open $(\mathrm{O})$ ]. There were 8 trees in the MI treatment, 10 trees in the MR treatment, and 6 trees in the MRS treatment. Measurements were made in September in 1967, and in late May in 1981 and 1991. Sample trees were all from the original study initiated in 1966. Integrity of litter treatments in the analysis of data was maintained, but we did not again remove litter from those canopy and open locations where it had been removed in 1966.

In 1966, we established 4 permanent belt transects 2.4 x $0.6 \mathrm{~m}$ beneath each mesquite tree radiating in the 4 cardinal directions from the bole. Four permanent belt transects $4.8 \mathrm{~m} \times 0.3 \mathrm{~m}$ were established in the open location $6 \mathrm{~m}$ from the base of each tree perpendicular to transects established under mesquite trees. Foliar cover (percent) of each understory species, including juvenile mesquite $(<1.5$ $m$ height), was measured as the vertical projection of the live foliage onto the ground surface using a $0.3 \mathrm{~m}^{2}$ frame for reference. Cover of mature mesquite trees and regrown mesquite trees was not measured. We recognize that foliar cover is a more volatile measure between seasons and years than basal cover, but this shortcoming is offset to some degree by the fact that all cover measurements were made by the same person.

Cover data were analyzed using a splitsplit-plot analysis of variance for repeated measures. We analyzed only those individual species with at least 100 observations. Data for those species were normal-

Table 1. July-September and annual precipitation $(\mathrm{cm})$ and departure from long-term means at the SRER study site (area 45 ) for the period of study.

Source: McClaran et al. (2002).

\begin{tabular}{|c|c|c|c|c|}
\hline Year & July-Sept & .Departure & Annual & Departure \\
\hline & & & 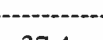 & --- \\
\hline 1965 & 14.5 & -5.9 & 37.4 & -0.3 \\
\hline 1966 & 28.6 & +8.2 & 44.6 & +6.9 \\
\hline 1967 & 20.4 & 0.0 & 45.5 & +7.7 \\
\hline 1968 & 18.6 & -1.8 & 33.7 & -4.0 \\
\hline 1969 & 28.8 & +8.4 & 35.3 & -2.4 \\
\hline 1970 & 30.3 & +9.9 & 40.4 & +2.7 \\
\hline 1971 & 23.0 & +2.6 & 43.8 & +6.1 \\
\hline 1972 & 14.3 & -6.1 & 34.5 & -3.2 \\
\hline 1973 & 9.7 & -10.7 & 25.2 & -12.5 \\
\hline 1974 & 31.4 & +11.0 & 45.8 & +8.1 \\
\hline 1975 & 18.2 & -2.2 & 29.7 & -8.0 \\
\hline 1976 & 20.1 & -0.3 & 32.2 & -5.5 \\
\hline 1977 & 21.0 & +0.6 & 43.9 & +6.2 \\
\hline 1978 & 14.7 & -5.7 & 57.3 & +19.2 \\
\hline 1979 & 14.7 & -5.7 & 31.1 & -6.6 \\
\hline 1980 & 16.2 & -4.2 & 31.2 & -6.5 \\
\hline 1981 & 19.2 & -1.2 & 42.0 & +4.3 \\
\hline 1982 & 23.2 & +2.8 & 39.5 & +1.8 \\
\hline 1983 & 28.8 & +8.4 & 61.8 & +24.1 \\
\hline 1984 & 42.3 & +21.9 & 67.6 & +29.9 \\
\hline 1985 & 19.4 & -1.0 & 42.1 & +4.4 \\
\hline 1986 & 16.5 & -3.9 & 33.8 & -3.9 \\
\hline 1987 & 18.4 & -2.0 & 41.2 & +3.5 \\
\hline 1988 & 27.2 & +6.8 & 49.2 & +11.5 \\
\hline 1989 & 10.0 & -10.4 & 27.0 & -10.7 \\
\hline 1990 & 32.4 & +12.0 & 47.0 & +9.3 \\
\hline 1991 & 15.3 & -5.1 & 39.0 & +1.3 \\
\hline Mean 1936-2001 & 20.4 & & 37.1 & \\
\hline
\end{tabular}

ly distributed and no transformations were required. Results for annual grass and forb plant groups are not reported here. These plant groups respond to summer rains and their data would have confounded the analysis because of different spring versus fall sampling periods among years. Main effects were mesquite tree treatments [T; MI, MR, and MRS] and years (Y). Splitplot effects were location [Lo; canopy (C) versus open $(\mathrm{O})]$ and litter $[\mathrm{L}$; intact $(\mathrm{LI})$ or removed (LR)]. The LSD test was used to compare means for significant $(\mathrm{P}<$ $0.05)$ main effects and interactions (Carmer and Swanson 1971). The unbalanced statistical design complicates individual means comparisons with 3-way interactions. For these means compar-

\section{Results} of variance, tree and litter treatments each significantly influenced cover of only 1 species (Lehmann lovegrass). Years significantly affected cover of every species and plant group, and location affected 8 of 10 species and plant groups (Table 2 ). However, interactions were significant for isons, we use an average LSD value.

Of the 4 treatment factors in the analysis 
all species and plant groups, except burroweed, and will receive the focus of our attention here.

\section{Perennial Grasses}

The perennial grass group included all of the perennial grass species listed in the description of the study area plus Lehmann lovegrass and perennial grasses that were only occasionally encountered. The $\mathrm{T} \times \mathrm{L}$ Lo $\mathrm{x} \mathrm{Y}$ interaction was significant at $P<0.0001$ (Table 2). For the experiment as a whole, foliar cover was 2- to 3fold greater in canopy locations. However, for the mesquite removed (MR) treatment in 1991, cover was similar in both canopy and open locations (Fig. 1a).

Despite overall similarity in cover for the litter intact (LI) and litter removed (LR) treatments, the $\mathrm{T} \times \mathrm{L} \times \mathrm{Y}$ interaction was significant $(P<0.0423$; Table 2). This significant interaction arises from several sources. In 1981 cover was greater for the mesquite intact (MI)-litter removed treatment combination, but was lower for the mesquite removed and sprouted (MRS)litter removed treatment combination (Fig. 1b). Moreover, cover for the mesquite intact-litter intact and mesquite removedlitter removed treatment combinations was significantly greater in 1991 than in 1981.

The $T \times L \times$ Lo interaction was significant at $\mathrm{P}<0.0209$ (Table 2). For the entire experiment, foliar cover was similar for the 2 litter treatments, but for the mesquite removed and sprouted treatment in the canopy location, foliar cover was 54 percent greater with litter intact than with litter removed (Fig. 1c).

\section{Arizona Cottontop}

Although cover of Arizona cottontop differed significantly among years and locations, these main effects are not meaningful in view of the significant $\mathrm{T} \times \mathrm{Lo} \mathrm{x}$ $\mathrm{Y}$ interaction (Table 2). In canopy locations, cottontop cover was 3- to 7-fold greater than in open locations for all mesquite tree treatments in 1967 and in 1991 for the MI treatment (Fig. 2).

\section{Black Grama}

For all combinations of variables, black grama foliar cover averaged only 0.42 percent and was 3.8-fold greater in open locations than under canopies. With one exception (MR 1981), cover in canopy locations was less than $0.3 \%$ (Fig. 3a). The relatively high cover in 1981 for MIopen $(1.39 \%)$ was significantly greater than that location in 1991. Likewise, the

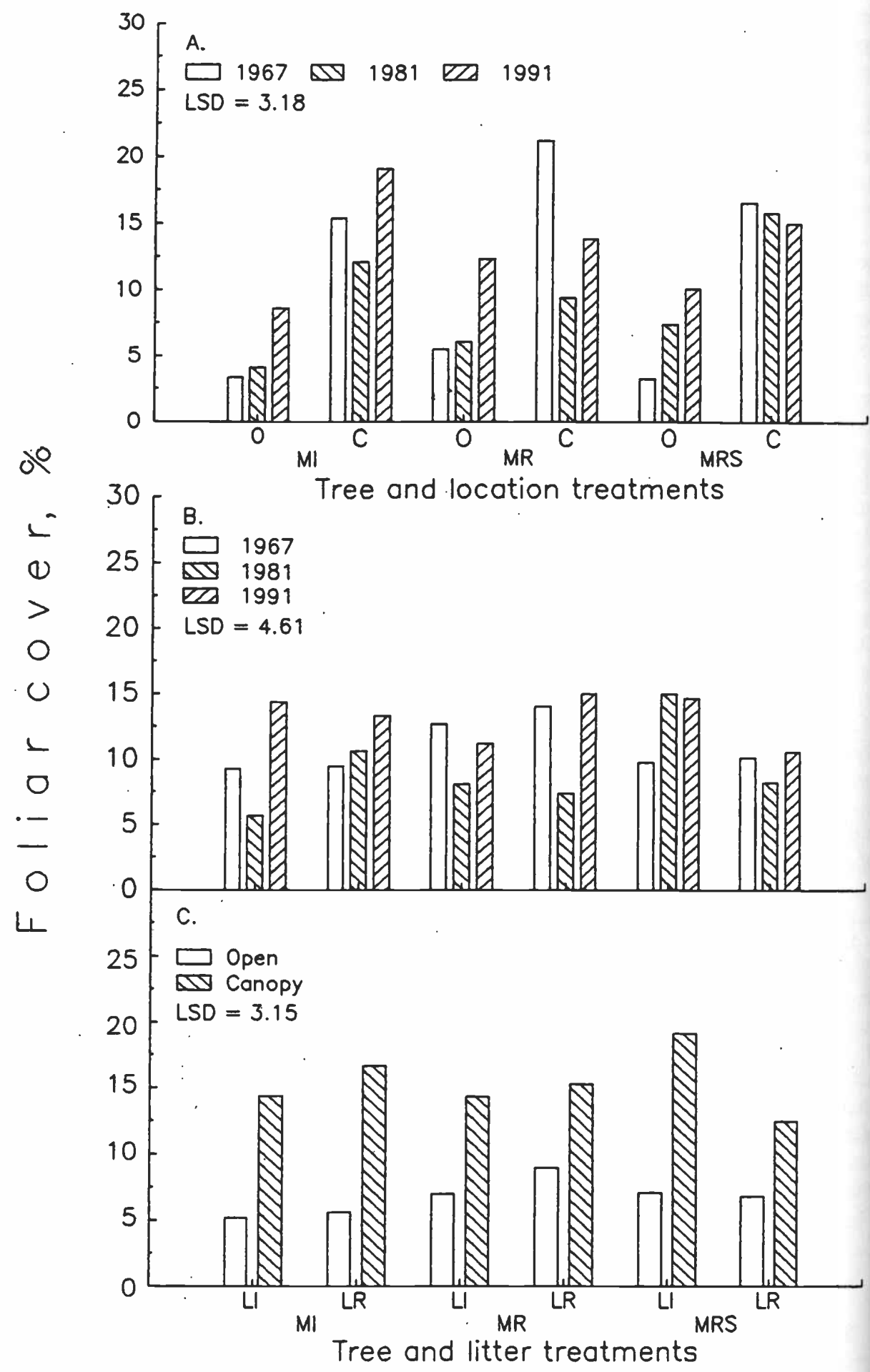

Fig. 1. Foliar cover of perennial grasses: a). Response to mesquite tree treatments, location, and year; b). Response to tree and litter treatments, and year; c). Response to tree and litter treatments, and location.

high value for MRS-open in 1981 (1.57\%) was higher than in 1967 or 1991 . These differences led to the significant $\mathrm{T} \times$ Lo $\mathrm{x}$ $\mathrm{Y}$ interaction.

The $T \times \mathrm{L} \times$ Lo interaction was significant at $\mathrm{P}<0.0312$. This interaction is explained by greater cover values in open locations for MI and MRS treatments than for the MR treatment and inconsistency in response to litter treatments (Fig. 3b). In the open location, greater cover occurred with litter removed for the MI treatment, but with litter intact for the MRS treatment. 
Table 2. Probability values from analysis of variance for foliar cover of selected species and groups of species for all variables and interactions.

\begin{tabular}{|c|c|c|c|c|c|c|c|c|c|c|}
\hline $\begin{array}{l}\text { Sources of } \\
\text { variation }\end{array}$ & $\begin{array}{c}\text { Perennial } \\
\text { grass }\end{array}$ & Shrubs & $\begin{array}{l}\text { Half- } \\
\text { shrubs }\end{array}$ & $\begin{array}{l}\text { Arizona } \\
\text { cottontop }\end{array}$ & $\begin{array}{l}\text { Black } \\
\text { grama }\end{array}$ & $\begin{array}{l}\text { Bush } \\
\text { muhly }\end{array}$ & $\begin{array}{l}\text { Lehmann } \\
\text { lovegrass }\end{array}$ & $\begin{array}{c}\text { Plains } \\
\text { bristlegrass }\end{array}$ & $\begin{array}{l}\text { Juvenile } \\
\text { mesquite }\end{array}$ & $\begin{array}{c}\text { Burro- } \\
\text { weed }\end{array}$ \\
\hline Trees (T) & 0.5787 & 0.8738 & 0.7709 & 0.4453 & 0.8977 & 0.7154 & 0.0363 & 0.8606 & 0.0612 & 0.9759 \\
\hline $\begin{array}{l}\text { Litter (L) } \\
T \times L\end{array}$ & $\begin{array}{l}0.7897 \\
0.0609\end{array}$ & $\begin{array}{l}0.8230 \\
0.2566\end{array}$ & $\begin{array}{l}0.6213 \\
0.7532\end{array}$ & $\begin{array}{l}0.2669 \\
0.4741\end{array}$ & $\begin{array}{l}0.9099 \\
0.1096\end{array}$ & $\begin{array}{l}0.9096 \\
0.0155\end{array}$ & $\begin{array}{l}0.0365 \\
0.0163\end{array}$ & $\begin{array}{l}0.7384 \\
0.3643\end{array}$ & $\begin{array}{l}0.7939 \\
0.8116\end{array}$ & $\begin{array}{l}0.3390 \\
0.4622\end{array}$ \\
\hline $\begin{array}{l}\text { Year }(Y) \\
\text { Tx Y } \\
\text { LxY } \\
\text { Tx L X Y }\end{array}$ & $\begin{array}{l}0.0003 \\
0.0123 \\
0.6933 \\
0.0423\end{array}$ & $\begin{array}{l}0.0062 \\
0.8381 \\
0.7763 \\
0.0667\end{array}$ & $\begin{array}{l}0.0001 \\
0.8738 \\
0.2547 \\
0.4833\end{array}$ & $\begin{array}{l}0.0001 \\
0.5404 \\
0.4142 \\
0.9725\end{array}$ & $\begin{array}{l}0.0325 \\
0.9254 \\
0.6474 \\
0.1050\end{array}$ & $\begin{array}{l}0.0001 \\
0.0054 \\
0.0644 \\
0.0206\end{array}$ & $\begin{array}{l}0.0001 \\
0.1705 \\
0.2134 \\
0.0424\end{array}$ & $\begin{array}{l}0.0052 \\
0.4477 \\
0.3101 \\
0.6479\end{array}$ & $\begin{array}{l}0.0001 \\
0.0224 \\
0.5415 \\
0.5648\end{array}$ & $\begin{array}{l}0.0001 \\
0.3721 \\
0.2800 \\
0.7184\end{array}$ \\
\hline $\begin{array}{l}\text { Location (L9) } \\
\text { T x Lo } \\
\text { L x Lo } \\
\text { Y x Lo } \\
\text { T x L x Lo } \\
\text { T x Lo X Y } \\
\text { L x Lo XY }\end{array}$ & $\begin{array}{l}0.0001 \\
0.0388 \\
0.1110 \\
0.0001 \\
0.0209 \\
0.0001 \\
0.8776\end{array}$ & $\begin{array}{l}0.0680 \\
0.3273 \\
0.6571 \\
0.5258 \\
0.0107 \\
0.0971 \\
0.0863\end{array}$ & $\begin{array}{l}0.0001 \\
0.8916 \\
0.5570 \\
0.0409 \\
0.0671 \\
0.6837 \\
0.2648\end{array}$ & $\begin{array}{l}0.0001 \\
0.0905 \\
0.1436 \\
0.0001 \\
0.3257 \\
0.0224 \\
0.3452\end{array}$ & $\begin{array}{l}0.0151 \\
0.3052 \\
0.6778 \\
0.1009 \\
0.0312 \\
0.0168 \\
0.6913\end{array}$ & $\begin{array}{l}0.0001 \\
0.0287 \\
0.2074 \\
0.0001 \\
0.0012 \\
0.0001 \\
0.0465\end{array}$ & $\begin{array}{l}0.0001 \\
0.0198 \\
0.0872 \\
0.0001 \\
0.2465 \\
0.0024 \\
0.0131\end{array}$ & $\begin{array}{l}0.0001 \\
0.2732 \\
0.5902 \\
0.0001 \\
0.0079 \\
0.0083 \\
0.0001\end{array}$ & $\begin{array}{l}0.1349 \\
0.1223 \\
0.0532 \\
0.0031 \\
0.0065 \\
0.0001 \\
0.0245\end{array}$ & $\begin{array}{l}0.0001 \\
0.8276 \\
0.9491 \\
0.2528 \\
0.0529 \\
0.4278 \\
0.6988\end{array}$ \\
\hline
\end{tabular}

\section{Bush Muhly}

Responses of bush muhly to experimental treatments were complex as all four, 3way interactions were highly significant (Table 2). The $\mathrm{T} \times \mathrm{L} \times$ Lo interaction was significant at $P<0.0012$. Cover was greater in canopy locations than in open locations by a factor averaging more than 5 for all combinations of tree and litter treatments, except for the MRS treatment with litter removed (Fig. 4a). Also, differences between litter treatments were significant only in the case of canopy locations for the MI and MRS treatments. Cover was greater with LR than LI in the canopy location of the MI treatment, but just the reverse in the canopy location of the MRS treatment.

Bush muhly responded strongly to location and year factors (Fig. 4b), but differences in cover among years in canopy locations caused a significant $\mathrm{T} \times \mathrm{L}$ Lo $\mathrm{X}$ interaction (Table 2). Except for the MRS treatment in 1967, cover was greater in canopy than open locations for all treatment and year comparisons. The most striking bush muhly response among years occurred in the canopy location of the MI treatment where cover increased more than four times between 1967 and 1991.

The pattern of bush muhly response to tree and litter treatments among years was not consistent resulting in the significant $\mathrm{T}$ $x$ L x Y interaction $(P<0.0206)$ (Table 2$)$. There was no difference in cover between LI and LR in any year for the MI tree treatments (Fig. 4c). The differential effect of the LI and LR treatments for the MRS treatment was pronounced in 1981 and 1991; cover was reduced 3- to 4 -fold by litter removal in both years.

Cover was several-fold greater in canopy than in open locations in all years and for both litter treatments except in
1967 with LI (Fig. 4d). In 1981 and 1991, cover was about 3-fold greater than in 1967 with LI. With LR from canopy locations, cover was 70 to $80 \%$ greater in 1991 than in 1967 or 1981 .

\section{Lehmann Lovegrass}

Significant 3-way interactions (Table 2) negated the relevance of main effects on Lehmann lovegrass. Although cover of Lehmann lovegrass overall increased greatly over the course of the experiment, cover increased significantly between 1967 and 1981 only for the MRS treatment (Fig. 5b). Between 1981 and 1991, cover increased significantly for all combinations of tree and location treatments, except for the canopy location of the MI treatment. Moreover, in 1991, MR was the only tree treatment that did not display a significant difference between locations
(Fig. 5b). These results account for the significant $\mathrm{T} \times$ Lo $\mathrm{x} Y$ interaction $(\mathrm{P}<$ 0.0024).

Cover of Lehmann lovegrass was similar for LI and LR litter treatments throughout the experiment except for the MRS treatment in 1991 (Fig. 5a). Cover increased significantly between 1981 and 1991 for all tree-litter treatment combinations except the MI-LR treatment, thus accounting for the significant $\mathrm{T} \times \mathrm{L} \times \mathrm{Y}$ interaction (Table 2). Cover for the litter intact treatment was significantly greater in open than canopy locations in 1991 (Fig. 5c). For the open location of the LR treatment, cover increased significantly between 1967 and 1981 and between 1981 and 1991. These differences gave rise to the significant $\mathrm{L} \times$ Lo $\mathrm{x} Y$ interaction $(\mathrm{P}<$ $0.0131)$.

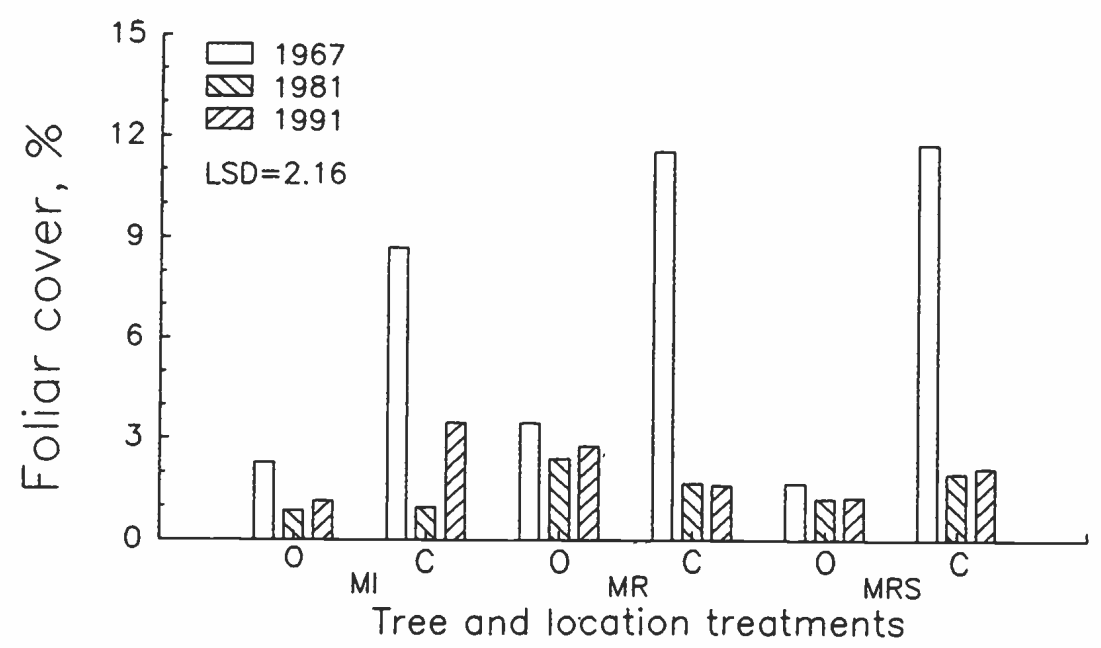

Fig. 2. Foliar cover of Arizona cottontop in response to mesquite tree treatments, location, and year. 


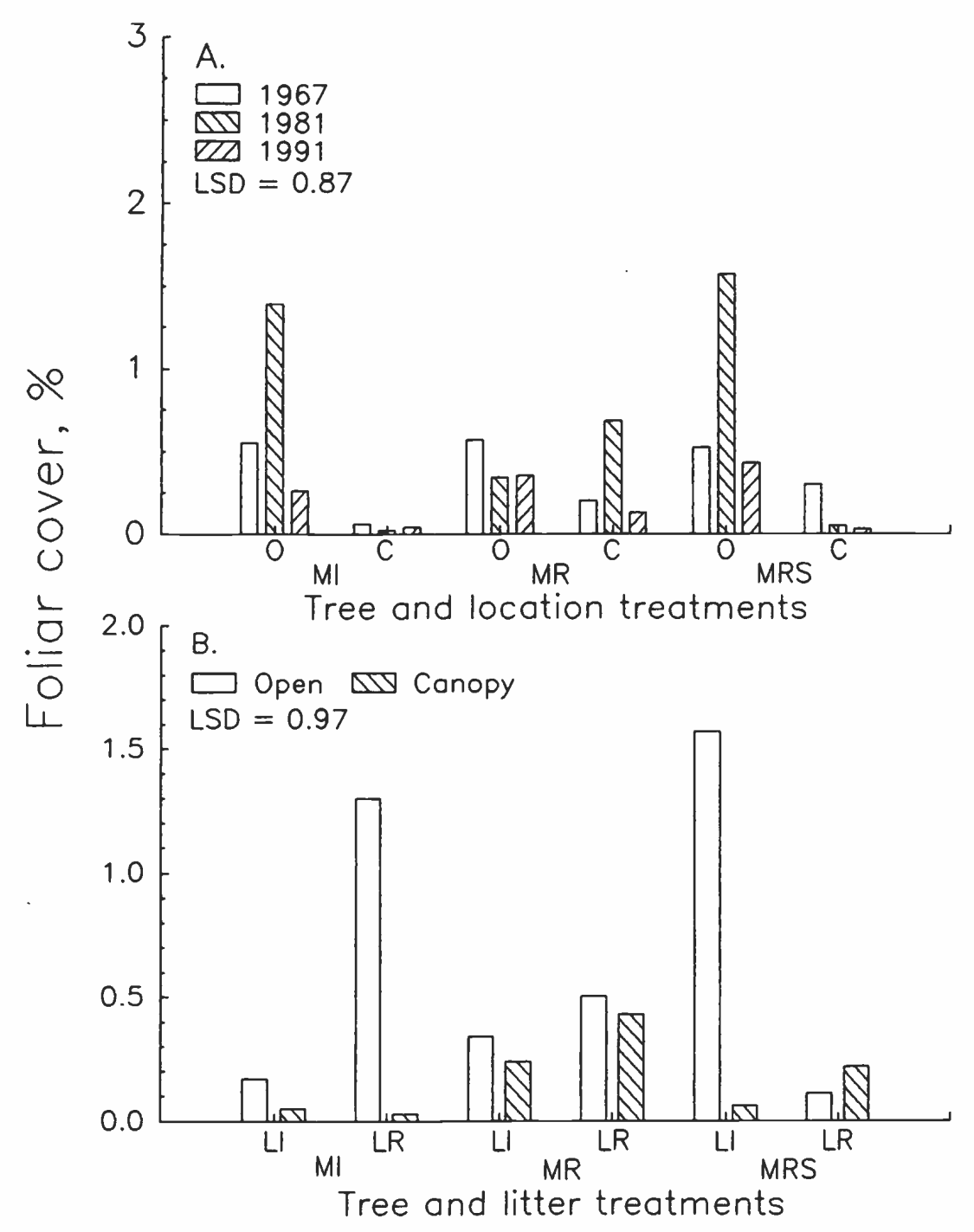

Fig. 3. Foliar cover of black grama: a). Response to mesquite tree treatments, location, and year; b). response to tree and litter treatments, and location.

\section{Plains Bristlegrass}

In general, cover of plains bristlegrass was similar for LI and LR litter treatments, and much greater in canopy than in open locations (Fig. 6a). Variable cover responses among years in the canopy location gave rise to the significant $\mathrm{L} x$ Lo $x \mathrm{Y}$ interaction $(\mathrm{P}<0.0001)$. In the open location, cover was similar among years (Fig. $6 a)$. In the canopy location in 1967, plains bristlegrass cover was lower with LR than LI. In 1981 and 1991, cover was similar for LR and LI treatments.

The $\mathrm{T} x$ Lo $\mathrm{x} Y$ interaction, significant at $P<0.0083$ (Table 2), resulted because of inconsistent responses of plains bristlegrass in the canopy location among years and tree treatments. There were no differences among years or tree treatments in the open location (Fig. 6b). Comparisons of open versus canopy locations reveal that cover was greater in the canopy loca-

\section{Halfshrubs}

Although year and location main effects significantly influenced foliar cover of the halfshrub plant group (Table 2), the Lo $x$ $\mathrm{Y}$ interaction was also significant $(\mathrm{P}<$ 0.0409 ). This interaction is explained by the more rapid increase in cover between 1967 and 1991 in canopy than in open locations (Fig. 7a). Cover in the open location did not differ significantly among years. Cover was significantly greater in open than in canopy locations every year. In the canopy location, cover increased significantly each year.

\section{Burroweed}

Burroweed was the only individual halfshrub species that occurred on enough transects to conduct a valid statistical analysis. It responded significantly to year and location effects, and no interactions were significant. Foliar cover increased significantly during each period of the study from 1.9 to 3.9 to $5.2 \%$. Cover was nearly twice as high in open locations (4.7 $\%$ ) as in canopy locations (2.7\%).

\section{Shrubs}

Cover of the shrub plant group increased about equally in canopy and open locations from 0.8 to $2.2 \%$ between 1967 and 1991. Cover was similar among tree and litter treatments, but was 2-fold greater in open than canopy locations (Fig. 7b). Hence, the significant $T \times \mathrm{L} \times$ Lo interaction $(P<0.0107$; Table 2). Shrub cover was much greater in open than in canopy locations for the MR-LR and MRS-LI treatment combinations. For the canopy location of the MI treatment, cover was 6fold less with the LR treatment than the LI treatment (Fig 7b).

None of the individual shrub species occurred on enough transects for separate statistical analyses. ment. For the MR treatment in the canopy location, cover declined successively over the course of the study. In the MRS canopy location, cover was similar among years.

Inconsistency in response of bristlegrass to location and litter treatments led to the significant $\mathrm{T} \times \mathrm{L} \times$ Lo interaction (Table 2 ). The usual large difference in cover between canopy and open locations did not occur for the MR treatment with LR or with the MRS treatment with LI (Fig. 6c). In the canopy location of the MR treatment, cover with LR was significantly reduced compared to LI. The reverse was true of the MRS treatment. Litter removal did not influence cover in the open location.

\section{Juvenile Mesquite}

Significant interactions involving tree treatments, locations, and years $(\mathrm{P}<$ 0.0001; Table 2) render significant main effects of these variables irrelevant. Through the course of the study, cover of juvenile mesquite increased for all combinations of tree treatments and location except for MI-canopy. The most pronounced effect was for the MRS treatment; here cover increased significantly between 1967 and 1981, then stabilized For MRS-canopy locations, juvenile mesquite was absent until 1991, when greater than $14 \%$ cover was observed. Location differences were observed only 

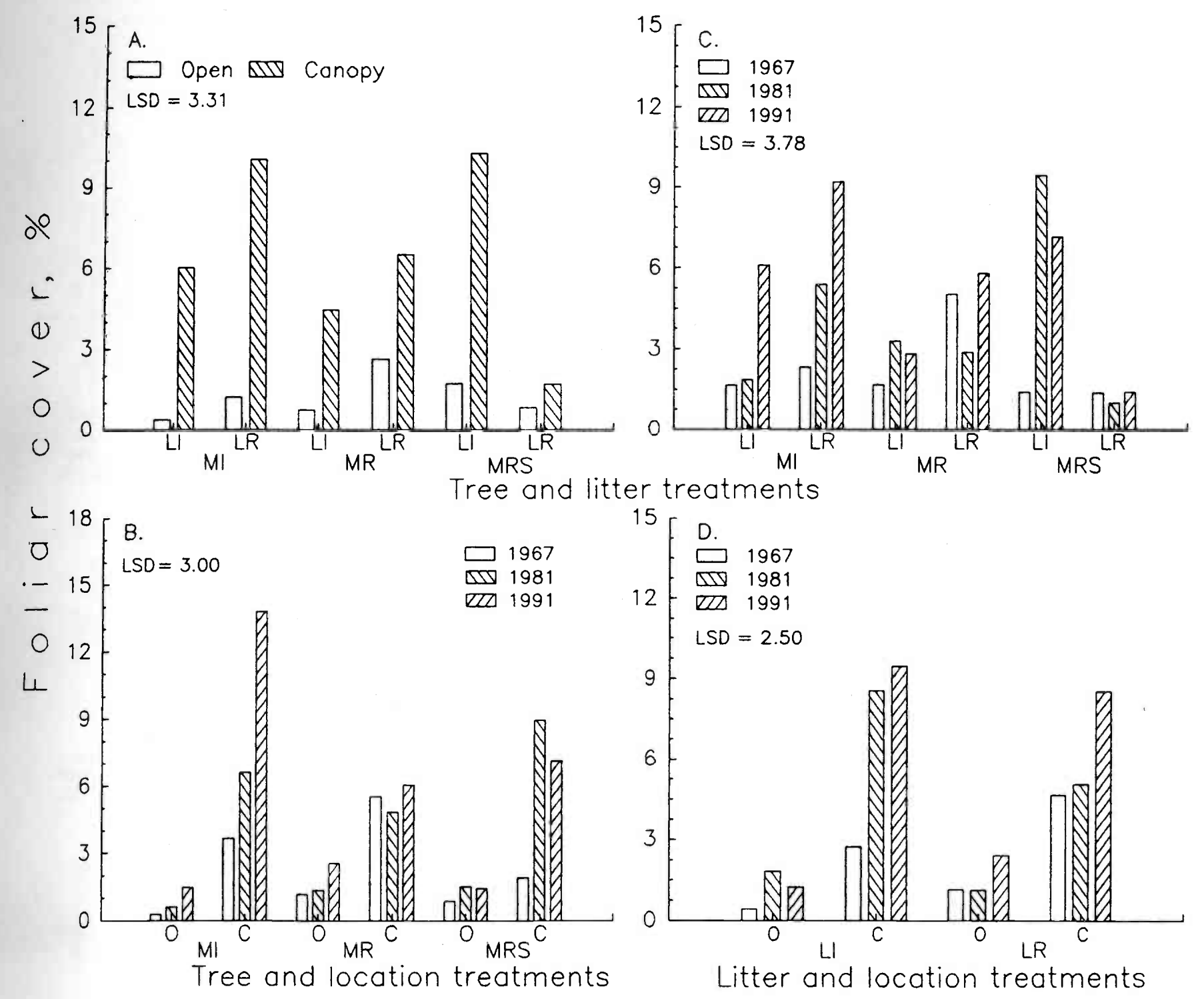

Fig 4. Foliar cover of bush muhly: a). Response to mesquite tree and litter treatments, and location; b). Response to tree treatments, location, and year; c). Response to tree and litter treatments, and year; d). Response to litter and location treatments, and year.

for MI in 1991 and MRS in 1981 and 1991.

Differential response of juvenile mesquite to litter treatments and location among tree treatments led to the significant $(\mathrm{P}<0.0065) \mathrm{T} \times \mathrm{L} \times$ Lo interaction. Litter treatment and location had no effect on cover for MI and MR treatments (Fig. $8 b)$. For the MRS treatment, in contrast, intact litter had opposite effects on cover in open (2.7-fold greater) and canopy (2.5fold less) locations compared to litter removed.

Average cover of new mesquite increased from $0.1 \%$ to $4.1 \%$ over the course of the experiment, but significant increases were noted only for the LI-open treatment between 1967 and 1981, and for canopy locations between 1981 and 1991 (Fig. 8c). Hence, the significant $(\mathrm{P}<$ $0.0245) \mathrm{L} x$ Lo $x$ Y interaction. Cover increased several-fold between 1981 and 1991 in canopy locations for both litter treatments.

\section{Discussion and Conclusions}

Salient vegetation changes between 1967 and 1991 were increased cover of juvenile mesquite, shrubs, halfshrubs (mainly burroweed), bush muhly, and Lehmann lovegrass and a decline in cover of Arizona cottontop and plains bristlegrass.

Increased cover of juvenile mesquite between 1981 and 1991 in the canopy location with the mesquite removed and sprouted (MRS) treatment compared to mesquite intact (MI) and mesquite removed (MR) may be attributed to a more favorable combination of soil, light, and temperature conditions for the MRS treatment. Soils under canopies of MI were significantly higher in carbon (C), nitrogen $(\mathrm{N})$, and available $\mathrm{N}$ than those of MR or MRS treatments or open locations in 1981 (Tiedemann and Klemmedson 1986, Klemmedson and Tiedemann 1986). Carbon and $\mathrm{N}$ concentrations and $\mathrm{N}$ availability of soil of the MRS treatment after 13 years were significantly lower than that for MI, but significantly greater than for MR. Based on previous research (Tiedemann and Klemmedson 1977), we would expect the MI treatment to have lower soil temperatures and higher levels of soil moisture than the MR treatment, and that values for these parameters for the MRS treatment would be intermediate between MI and MR treatments. Intermediate levels of light and soil temperature, moisture, and $\mathrm{N}$ in the canopy 


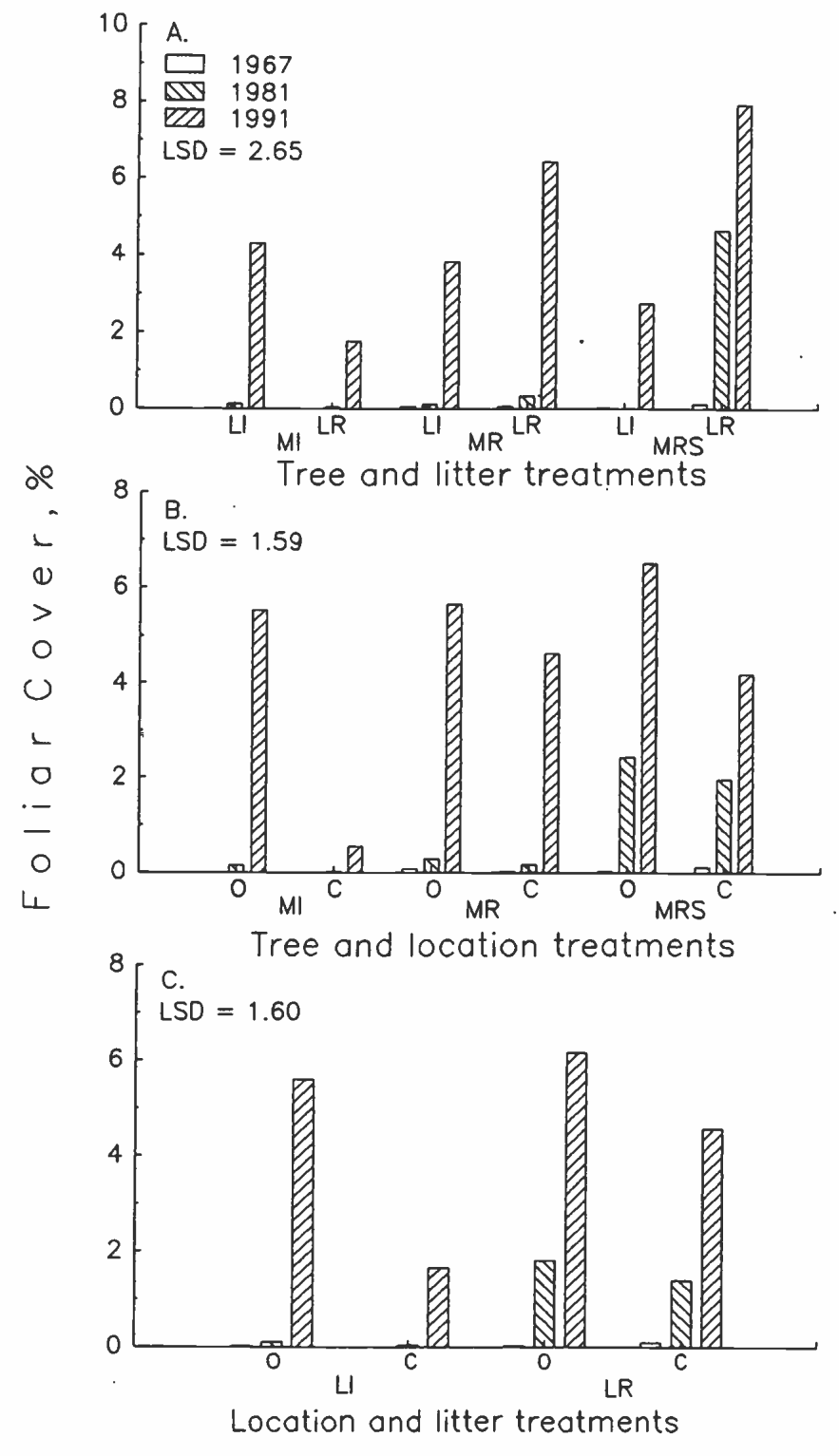

Fig. 5. Foliar cover of Lehmann lovegrass: a). Response to mesquite tree and litter treatments, and year; b). Response to tree treatments, location, and year; c). Response to litter and location treatments, and year.

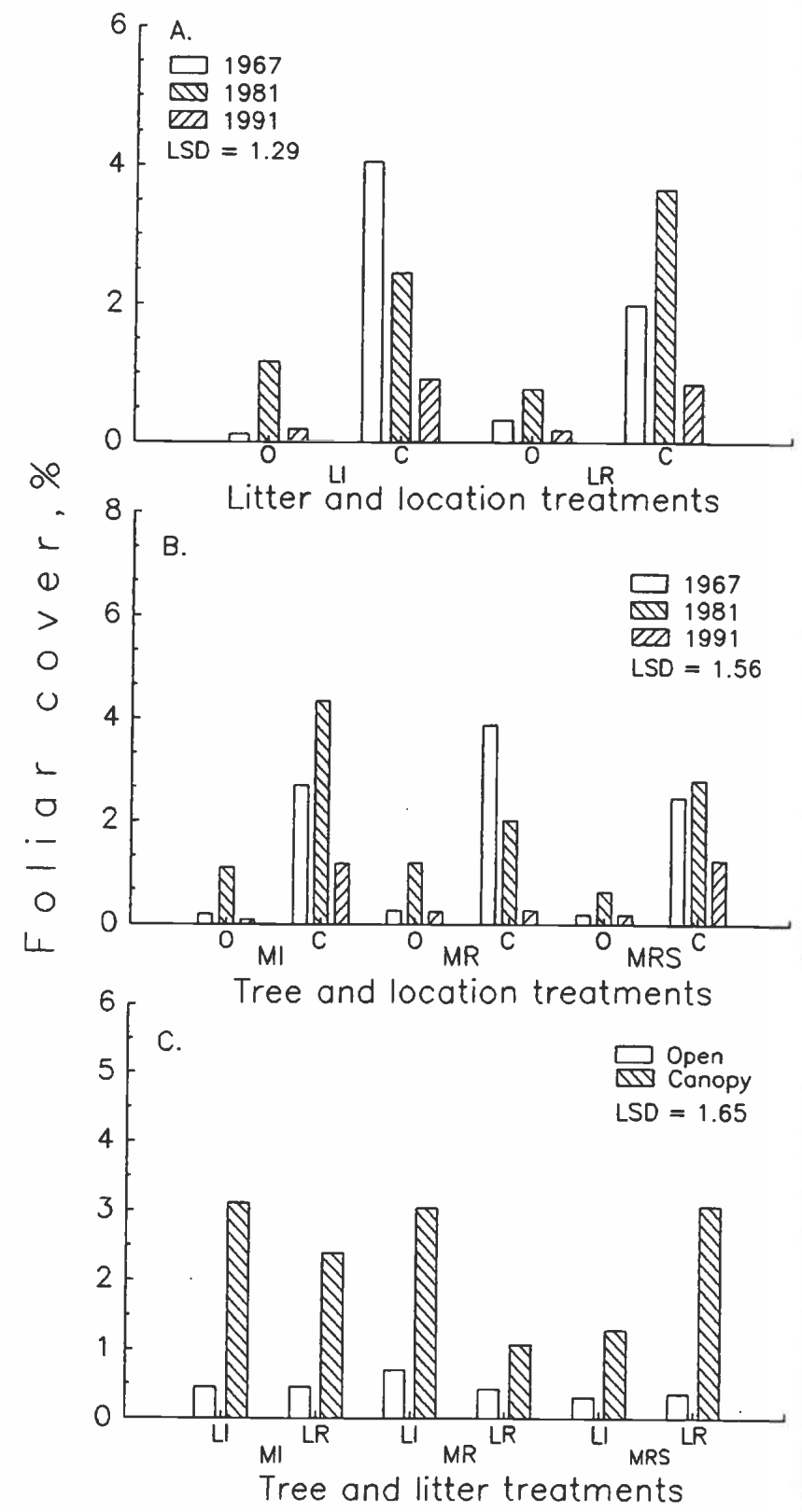

Fig. 6. Foliar cover of plains bristlegrass: a). Response to litter treatments, location, and year; b). Response to mesquite tree treatments, location, and year; c). Response to tree and litter treatments, and location. location of the MRS treatment (i.e. compared to MI and MR) apparently were conducive to more rapid development of mesquite than the other 2 treatments. Despite improved moisture and reduced temperature of soils of the MI treatment (Tiedemann and Klemmedson 1977), reduced light of the MI treatment compared to MRS may have been the most important factor that limited development of juvenile mesquite.

Greater abundance of black grama in open locations and the opposite pattern for Arizona cottontop, plains bristlegrass, and bush muhly confirms observations from our original study on this site (Tiedemann and Klemmedson 1977) and more recent results of Van Deren (1993) and Livingston et al. (1997). In a shade response study, Arizona cottontop, plains bristlegrass, and bush muhly responded to increasing shade with increasing leaf length (Tiedemann et al. 1971). Although all 3 species made their best growth in full sun, leaf length response to shade indicates that they are facultative skiophytes (plants which are heliophytes but able to adapt to shaded conditions). Leaf length of black grama, on the other hand, did not change with increasing shade suggesting that it is an obligate heliophyte and is adapted primarily to open locations.
Bush muhly was more strongly influenced by location and mesquite treatments than any other species as manifested by 4 fold greater cover in canopy than open locations and greater cover with MI than MR in canopy locations. The stepwise decline of bush muhly in canopy locations between MI and MR treatments suggests that bush muhly was sensitive to sequentially higher light environments of MRS and MR treatments compared to those of the MI treatment. Combined treatments of MRS and litter intact (LI) enhanced cover development of the perennial grass group and bush muhly, in particular. Litter removal reduced cover of perennial grass- 


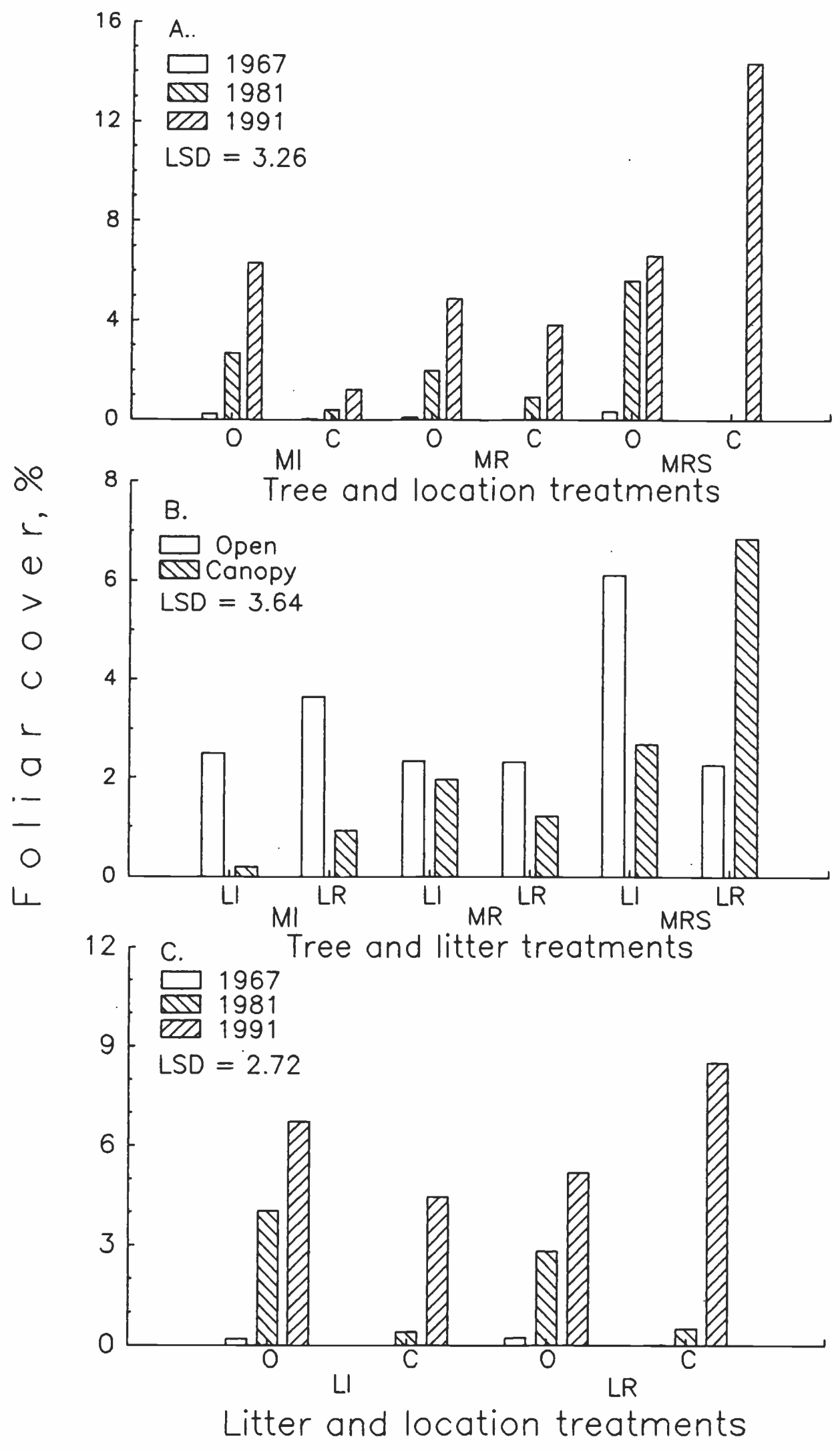

Fig. 8. Foliar cover of juvenile mesquite: a). Response to mesquite tree treatments, location, and year; b). Response to tree and litter treatments, and location; c). Response to litter and location treatments, and year. year periods and a 5-year period (1981 through 1985) characterized by above average annual precipitation (Table 1; McClaran 2003). On a larger scale, enrichment of atmospheric $\mathrm{CO}_{2}$ may confer an advantage to mesquite for establishment in water-limited grasslands (Polley et al. 2002).

Results suggest a potential strategy for maintaining diversity of native perennial grass species. Mature mesquite trees may provide a refuge for shade-adapted grasses such as Arizona cottontop, bush muhly, and plains bristlegrass. This possibility seems to deserve exploration throughout the range of mesquite in the southwest desert grassland.

\section{Literature Cited}

Anable, M.E., M.P. McClaran, and G.B. Ruyle. 1992. Spread of introduced Lehmann lovegrass Eragrostis lehmanniana Nees. in southern Arizona, USA. Biol. Conserv. 61:181-188.

Angell, D.H. and M.P. McClaran. 2001 Long-term Influences of livestock management and a non-native grass on grass dynamics in the desert grassland. J. Arid Environ. 49:507-520

Archer, S., C. Scifres, and C. R. Bassham. 1988. Autogenic succession in a subtropical savanna parkland. Ecol. Monogr. 58:111-127.

Barth, R.C. and J.O. Klemmedson. 1978. Shrub induced spatial patterns of dry matter, nitrogen, and organic carbon. Soil Sci. Soc Amer. J. 42:804-809.

Barth, R.C. and J.O. Klemmedson. 1982 Amount and distribution of dry matter, nitrogen, and organic carbon in soilplant systems of mesquite and palo verde. J. Range Manage. 35:412-418.

Belsky, A.J. 1994. Influences of trees on savanna productivity: tests of shade, nutrients, and tree-grass competition. Ecol. 75:922-932.

Belsky, A.J., R.G. Amundson, J.M Duxbury, S.J. Riha, A.R. Ali, and S.M. Mwonga. 1989. The effects of trees on their physical, chemical and biological environments in a semi-arid savanna in Kenya. J. Appl. Ecol. 26:1005-1024.

Breckenfeld, D.J. and D. Robinett. 1997. Soil and range resources inventory of the Santa Rita Experimental Range, Pima County, Arizona. USDA Natural Resources Conservation Service in cooperation with University of Arizona, Tucson, Ariz.

Bush, J.K. and O Bush, J.K. and O.W. Van Auken. 1989. Soil resource levels and competition between woody and herbaceous species. Bull. The Torrey Bot. Club $116(1): 22-30$. 
Cable, D.R. 1969. Competition in the semidesert grass-shrub type as influenced by root systems, growth habits, and soil moisture extraction. Ecol. 50:27-38.

Cable, D.R. 1971. Lehmann lovegrass on the Santa Rita Experimental Range, 1937-1968. J. Range Manage. 24:17-21.

Cable, D.R. 1976. Twenty years of changes in grass production following mesquite control and reseedlng. J. Range Manage. 29:286-289.

Carmer, S.G. and M.R. Swanson. 1971. Detection of differences between means: a Monte Carlo study of five pairwise multiple comparison procedures. Agron. J. 36:940-945.

Cox. J.R. and G.B. Ruyle. 1986. Influence of climatic and edaphic factors on the distribution of Eragrostis lehmanniana Nees in Arizona, USA. J. Grassl. Soc. South Africa 3:25-29.

Cox. J.R., M.H. Martin-R, F.A. Ibarra-F, J.H. Fourie, N.F.G Rethman, and D.G. Wilcox. 1988. The Influence of climate and soils on the distribution of four African grasses. J. Range Manage. 41:127-129.

Jenny, H. 1930. A study of the influence of climate upon nitrogen and organic matter content of the soil. Missouri Agr. Exp. Sta. Res. Bull. 152.

Julander, O. 1945. Drought resistance in range and pasture plants. Plant Physio. 20:573-599.

Kincaid, D.R., G.A. Holt, P.D. Dalton, and J. Tixier. 1959. The spread of Lehmann lovegrass as affected by mesquite and native perennial grasses. Ecol. 40:738-742.

Klemmedson, J.O and A.R. Tiedemann. 1986. Long-term effects of mesquite removal on soil characteristics: II. Nutrient availability. Soil Sci. Soc. Amer. J. 50:476-480.

Livingston, M., B.A. Roundy, and S.E. Smith. 1997. Association of overstory plant canopies and native grasses in southern Arizona. J. Arid Environ. 35:441-449.
Martin, S.C. 1966. The Santa Rita Experimental Range. USDA Forest Service Res. Paper RM-22. Rocky Mountain Forest and Range Experiment Station, Fort Collins, Colo. 24 p.

Martin, S.C. 1975. Ecology and management of southwestern semidesert grass-shrub ranges: The status of our knowledge. USDA Forest Service Res. Paper RM-156. Rocky Mountain Forest and Range Experiment Station, Fort Collins, Colo. $39 \mathrm{p}$.

Martin, S.C. and H.L. Morton. 1993. Mesquite control increases grass density and reduces soil loss in southern Arizona. J. Range Manage. 46:170-175.

McClaran, M.P. 2003. A century of vegetation change on the Santa Rita Experimental Range. Pages 16-33. In: McClaran, M.P., P.F. Ffolliott, and C.B. Edminster (Tech. Coords.) Santa Rita Experimental Range: 100 years (1903-2003) of accomplishments and contributions. Conference Proceedings, Oct. 30 to Nov. 1, 2003, Tucson, Arizona. USDA Forest Service Conf. Proc. RMRS-P30. Rocky Mountain Research Station, Ogden, Utah.

McClaran, M.P. and M.E. Anable. 1992. Spread of introduced Lehmann lovegrass along a grazing intensity gradient. J. Appl. Ecol. 29:92-98.

McClaran, M.P., D.L. Angell, and C. Wissler. 2002. Santa Rita Experimental Range Digital Database User's Guide. USDA Forest Service General Technical Report RMRS-GTR-100. Rocky Mountain Research Station, Ogden, Utah. 13 Pages.

Parker, K.W. and S.C. Martin. 1952. The mesquite problem on southern Arizona ranges. USDA Circ. No. 908.70 p.

Polley, W.H., H.B. Johnson, and C.R. Tischler. 2002. Woody invasion of grasslands: evidence that $\mathrm{CO}_{2}$ enrichment indirectly promotes establishment of Prosopis glandulosa. Plant Ecol. 164:85-94.
Roundy, B.A. and S. H. Biedenbender. 1996. Germination of warm-season grasses under constant and dynamic temperatures. J. Range Manage. 49:425-431.

Roundy, B.A., R.B. Taylorson, and L.B. Sumrall. 1992. Germination responses of Lehmann lovegrass to light. J. Range Manage. 45:81-84.

Sellers, W.D. 1960. Arizona climate. Institute of Atmospheric Physics, Univ. of Ariz., Tucson, Ariz. 60 p.

Sumrall, L.B., B.A. Roundy, J.R. Cox, and V.K. Winkel. 1991. Influence of canopy removal by burning or clipping on emergence of Eragrostis lehmanniana seedlings. Int. J. Wildland Fire 1:35-40.

Tiedemann, A.R. and J.O. Klemmedson. 1973a. Effect of mesquite on physical and chemical properties of the soil. J. Range Manage. 26:27-29.

Tiedemann, A.R. and J.O. Klemmedson. 1973b. Nutrient availability in desert grassland soils under mesquite Prosopis juliflora trees and adjacent open areas. Proc. Soil Sci. Soc. Amer. 37:107-111.

Tiedemann, A.R. and J.O. Klemmedson. 1977. Effect of mesquite trees on vegetation and soils in the desert grassland. J. Range Manage. 30:361-367.

Tiedemann, A.R. and J.O. Klemmedson. 1986. Long-term effects of mesquite removal on soil characteristics: I. Nutrients and bulk density. Soil Sci. Soc. Amer. J. 50:472-475.

Tiedemann, A.R., J.O. Klemmedson, and P.R. Ogden. 1971. Response of four perennial southwestern grasses to shade. J. Range Manage. 24:442-447.

Turner, R.M., H.A. Ochung', and J.B. Turner. 1998. Kenya's changing landscape. The Univ. of Ariz. Press, Tucson, Ariz. 177 p.

Van Deren, K.J. 1993. The influence of invasive Lehmann lovegrass on two native grasses in the semi-desert grassland. M. S. Thesis, Univ. of Ariz., Tucson, Ariz. 62 p. 